\title{
Importance of anatomic variations in secundum ASD: residual ASD detected on postoperative 31st year
}

\author{
Ufuk Yetkin*, Nihan Karakaş, Mehmet Balkanay, Ali Gürbüz \\ From World Society of Cardiothoracic Surgeons 25th Anniversary Congress, Edinburgh \\ Edinburgh, UK. 19-22 September 2015
}

\section{Background/Introduction}

Secundum ASD is the most common congenital defect seen in adulthood. Anatomical variations are the most important factors in decision making of surgical procedure.

\section{Aims/Objectives}

Our case was 57 year-old male. He underwent secundum ASD repair 31 years ago. His complaint was progressive dyspnoea and for about 1 year.

\section{Method}

Transthoracic echocardiography revealed residual ASD and transosophageal echocardiography showed that this ASD is a patch tear close to the orifice of inferior vena cava in size of $15 \times 6 \mathrm{~mm}$. Coronary angiography and cardiac catherization were performed and results were normal. Cavity sizes and pulmonary artery pressure were normal.

\section{Results}

He was taken to operation, pericardium was very adherent and epicardium was cleaned with gentle dissection. Inferior vena cava cannulation was performed and the cannula was misguided to left atrium transseptally, it was detected by the help of blood color and cannula was redirected to IVC by special stretching manuevre. Under total cardiopulmonary bypass fossa ovalis type secundum ASD was explored and there was no patch component. An untouched sinus venous type ASD in size of $10 \times 15 \mathrm{~mm}$ near IVC was detected and repaired with prolen sutures supported with teflon pledget. Successful decanulation and hemostasis after optimal dearing and residual ASD check, operation was terminated. No early or late complication

\footnotetext{
Department of Cardiovascular Surgery, Katip Celebi University Izmir Ataturk
} Training and Research Hospital, Izmir, Turkey was seen postoperatively and TEE showed no residual ASD.

\section{Discussion/Conclusion}

We suggest that secundum ASD should be evaluated carefully especially by young surgeons as it may have anatomical variations and different localizations.

\section{Consent}

Written informed consent was obtained from the patient for publication of this Case report and any accompanying images. A copy of the written consent is available for review by the Editor-in-Chief of this journal.

Published: 16 December 2015

doi:10.1186/1749-8090-10-S1-A225

Cite this article as: Yetkin et al:: Importance of anatomic variations in secundum ASD: residual ASD detected on postoperative 31st year. Journal of Cardiothoracic Surgery 2015 10(Suppl 1):A225.

Submit your next manuscript to BioMed Central and take full advantage of:

- Convenient online submission

- Thorough peer review

- No space constraints or color figure charges

- Immediate publication on acceptance

- Inclusion in PubMed, CAS, Scopus and Google Scholar

- Research which is freely available for redistribution 